\title{
Evaluating the performance of modern rural management (Dehyari) in improving social contexts and attracting financial resources for the development of rural entrepreneurship in Khalilabad
}

\section{Evaluar el desempeño de la gestión rural moderna (Dehyari) en la mejora de los contextos sociales y la atracción de recursos financieros para el desarrollo Del espíritu empresarial rural en} Khalilabad

\author{
Ayoub Akherati Ivari
}

PhD Student, Department of Geography and Rural Planning, Mashhad Branch, Islamic Azad University, Mashhad, Iran

ORCID ID: https://orcid.org/0000-0003-4460-3965

\section{Hamid Jafari}

Department of Geography, Mashhad Branch, Islamic Azad University, Mashhad, Iran ORCID ID: https://orcid.org/0000-0002-2007-562X

\section{Mohammad Ali Ahmadian}

Department of Geography, Mashhad Branch, Islamic Azad University, Mashhad, Iran ORCID ID: https://orcid.org/0000-0003-3414-4371

*Correspondence

Email: jafari1421@mshdiau.ac.ir
Cite as:

Akherati Ivari, A., Jafari, H., \& Ahmadian, A, M. (2021). Evaluating the performance of modern rural management (Dehyari) in improving social contexts and attracting financial resources for the development of rural entrepreneurship in Khalilabad. Propósitos y Representaciones, 9 (SPE3), e1018. Doi: http://dx.doi.org.10.20511.pyr2021.v9nSPE3.1018 


\section{Summary}

Entrepreneurship is one of the most important tools for planning and achieving the development of rural communities. Today, due to the problems in these communities, attention and emphasis on rural entrepreneurship is very important; Because entrepreneurship can play an effective role in improving the economic and living conditions of villages by creating new employment and income opportunities, and the present study aims to evaluate the performance of modern rural management (rural) in improving social contexts and attracting financial resources. It has been prepared for the development of rural entrepreneurship in Khalilabad city. The present research is applied in terms of purpose and in terms of descriptive-analytical method, which used library and field methods to collect information and a researcher-made questionnaire for field data. The sample population was randomly studied using Cochran's formula including 370 people in 23 villages of the city. The results obtained in the villages of the city show that the performance of rural villagers in Khalilabad city in order to develop rural entrepreneurship has been weak. Villages have not improved the social context and attracted financial resources for the development of rural entrepreneurship and have not been able to achieve the desired goals.

Keywords: Performance evaluation, Rural management, Rural entrepreneurship, Khalilabad city.

\section{Resumen}

El emprendimiento es una de las herramientas más importantes para planificar y lograr el desarrollo de las comunidades rurales. Hoy, debido a los problemas en estas comunidades, la atención y énfasis en el emprendimiento rural es muy importante; Porque el espíritu empresarial puede desempeñar un papel eficaz en la mejora de las condiciones económicas y de vida de las aldeas mediante la creación de nuevas oportunidades de empleo e ingresos, y el presente estudio tiene como objetivo evaluar el desempeño de la gestión rural moderna (rural) en la mejora de los contextos sociales y la atracción de recursos financieros. Ha sido preparado para el desarrollo del espíritu empresarial rural en la ciudad de Khalilabad. La presente investigación se aplica en términos de propósito y en términos de método descriptivo-analítico, que utilizó métodos de biblioteca y de campo para recolectar información y un cuestionario elaborado por investigadores para datos de campo. La población de la muestra se estudió aleatoriamente utilizando la fórmula de Cochran que incluyó a 370 personas en 23 aldeas de la ciudad. Los resultados obtenidos en las aldeas de la ciudad muestran que el desempeño de los pobladores rurales de la ciudad de Khalilabad para desarrollar el espíritu empresarial rural ha sido débil. Las aldeas no han mejorado el contexto social y atraído recursos financieros para el desarrollo del espíritu empresarial rural y no han podido alcanzar las metas deseadas.

Palabras clave: Evaluación del desempeño, gestión rural, emprendimiento rural, ciudad de Khalilabad.

\section{Introduction}

Today, many rural areas around the world, especially in developing countries, are experiencing problems caused by recession, stagnation and recession, which are due to the lack of economic diversity, lack of entrepreneurial outlook and the like, as a result of each Rural areas are facing strategic challenges of increasing the development gap between urban and rural areas (lack of income from man-made resources, unemployment, low income, low productivity, increasing rural migration and environmental degradation, etc.). Development process Economic development in developed countries indicates the fact that the economy is influenced by entrepreneurship (Yadollahi, 2015: 24). 
It is worth mentioning that looking at sustainable development, entrepreneurship in rural areas from economic aspects helps to create employment, use of socio-institutional financial resources to improve social justice, promote participation and environmental rights, resource management, healthy ecosystem and diversity Biology is important in entrepreneurship policies (Rokanuddin Eftekhari et al., 2010: 40).

Various studies have shown that one of the most important development goals in both urban and rural areas is to create employment and welfare and its most important mechanism and tool is entrepreneurship (Rezvani et al., 2008: 46).

Today, rural development is closely linked to entrepreneurship, and entrepreneurship can accelerate the development process in rural areas and facilitate business processes and improve rural incomes. Since the study area is experiencing a decrease in rural population and migration from rural areas has increased during recent censuses, therefore, one of the main causes of migration is lack of income and unemployment. This research seeks to evaluate the factors affecting the development of rural entrepreneurship in the villages of Torbat-e Heydarieh city in order to help increase its role and ultimately reduce migration by identifying their issues and problems and providing appropriate solutions.

Khalilabad city is located $243 \mathrm{~km}$ southwest of Mashhad. According to the results of the general population and housing census of 2016, 51701 people had a population of 32490 people (63\%) living in 27 villages. Khalilabad city is one of the cities that has experienced a new approach to rural management (Dehyari) at a desirable level. According to the available statistics, the number of permits issued for the establishment of villages in Khalilabad city has been 23, and the same number of villages has been established, which has a ratio of $100 \%$ of the established villages to $100 \%$ licenses. According to seventeen years of experience in rural areas, by recognizing and using different aspects and the current performance of the new village management, ie rural areas and the supervisory role of rural Islamic councils as representatives of villagers and also the participation of villagers to achieve Development of rural entrepreneurship and finally sustainable rural development. Therefore, the title of this study was "Evaluating the performance of modern rural management (Dehyari) in improving social contexts and attracting financial resources for the development of rural entrepreneurship in Khalilabad city" and the main orientation of this research is to answer this question:

What has been the performance of rural areas in the field of rural entrepreneurship development in the study area?

\section{The importance of the subject of research}

Today, around the world, changes in population, technology, inflation, unemployment, underdevelopment and other environmental factors have changed human society in a very different way than in the past and have posed new challenges and opportunities. Between the reactions and responses to these changing forces, there is a strong emphasis on entrepreneurship by governments, organizations, and public opinion, and is referred to as the engine of economic development. The importance of entrepreneurship can be examined from various aspects, for example, developed countries revitalize their economies through creative activities and solve unemployment problems by creating new job opportunities resulting from entrepreneurial activities. It is accepted as a potential catalyst for technological progress and product and market innovation (Yonca \& Akdeniz, 2006: 26).

Today, one of the effective strategies in the comprehensive and self-sustainable development of rural areas is to use the participation and capabilities of the people, especially the villagers, for the development of rural areas in all its dimensions. Based on the needs and abilities of different 
groups living in the village, in various and necessary issues, the local and indigenous environment is created in order to implement rural development programs. In recent years, Islamic councils and villages have been defined as the management of villages and can contribute to the development of policies, management and implementation of various educational programs, development of the necessary infrastructure, helping to attract financial resources and the like. Provide rural entrepreneurship (Hashemi et al., 2011: 93).

Theoretical

\section{- Rural management}

Rural management is considered to be the administration of rural affairs, which helps to balance the affairs of the village and also to improve the quality of life of the villagers. Thus, rural management is both a kind of intellectual system consisting of executive methods and a scientific subject and expertise, so it must be researchable and thoughtable, as well as teaching others. The goal of rural management is to achieve development, followed by sustainable rural development. Rural management is in fact the process of organizing and guiding the community and the rural environment through the formation of organizations and institutions. These organizations and institutions are the tools or means of achieving the goals of rural society, the goals that people draw and accept. Rural development management is also a multifaceted process that includes the three pillars of people, government and public institutions. In this process, with the participation of the people and through rural organizations, rural development programs and plans are developed and implemented and are monitored and evaluated (Rezvani, 2004, 211).

\section{- Entrepreneurship}

Entrepreneurship refers to the process of creating new value (material or spiritual) through a committed effort, taking into account the risks involved. The word entrepreneurship comes from the French word commitment. Entrepreneurship first came to the attention of economists, and all schools of economics from the 16th century until now have somehow described entrepreneurship in their theories. Joseph Schumpeter (1934) calls the entrepreneurial process "creative destruction." In other words, the decisive feature in entrepreneurship is doing new things or inventing new methods in current affairs. There are many different definitions of entrepreneurship. Some call it innovation, some equate it with risk-taking, some as market stabilizing and balancing force, and some equate it with creating a new business (or building a business based on a new idea) or development. They know the existing business (Safety et al., 2009: 11).

\section{- Rural entrepreneurship}

Entrepreneurship as a process, the phenomenon of system and leader, not only creates jobs for the wider rural community in the land, but also strengthens the skills and capacity of the local community, transforms the income cycle in the villages and takes a new shape. Rural entrepreneurship is seen as a strategy for diversification and job creation, with politicians recognizing it as a key solution to preventing rural turmoil, with farmers as a means of improving farmers' incomes, and its women. Are considered as a possibility to work in the vicinity of their home (Heaton, 2005: 1).

\section{Research purposes}

The objectives of this research are as follows:

1- Recognizing the geographical features of a part of the land (study area);

2- Identifying issues and problems related to rural entrepreneurship;

3- Providing solutions and suggestions to solve the above-mentioned issues and problems in order to increase the living standards of the villagers and reduce migration. 


\section{Research background}

Mirza Amini (2006) in his article entitled "Strategies for Rural Entrepreneurship Development and Job Creation" has concluded that by applying the approach of "localization" and using the initiatives and knowledge of other nations, local methods, plans and programs can be effectively Designed and executed.

Nemati and Badri (2007) in their article entitled "Assessing the functional role of the new rural management system in a comparative comparison of active rural areas in small and large villages of Golestan province" have concluded that structural, social and economic factors are closely related to the rate Dehyari is successful in small villages. In addition, Dehyari has been more successful in small villages than small villages due to higher per capita credit.

Saeedi (2009) in his research entitled "The role of modern rural management in entrepreneurship and job creation in rural areas" first stated that modern rural management using knowledge-based economy can have a very important impact on the success and survival of the following organizations Then explains that entrepreneurship as a new phenomenon in the economy, has an effective role in the economic development and progress of countries, and ultimately the result is that managers and those involved in the field of modern rural management should Take steps in the cycle process by increasing new knowledge and increase productivity, entrepreneurship and employment in rural areas.

Tusi et al. (2014) in their article entitled "Rural Entrepreneurship and Determining the Factors Affecting It (Case Study: Villages of Minoodasht County)" have concluded that Golestan province, like other parts of the country, faces such problems that Principled planning and the creation of rural employment and entrepreneurship in this province, in terms of agriculture, industry, services and tourism, can lead to a comprehensive and more prosperous. Considering the available statistics in this field, the importance of this issue in Minoodasht city becomes quite obvious.

Ebrahimi et al. (2014) in their article entitled "Components of Rural Entrepreneurship Development (Case Study: Kerman City)" stated that entrepreneurs are generally young and the rate of entrepreneurship varies among the average to high level and most of them have no education. They are academics and in terms of entrepreneurship components, the best situation is related to psychological, skill, personal and infrastructural components, respectively.

Torkashvand (2014) in his article entitled "Strategy for participatory development of rural entrepreneurship studied in Zand and Saman districts (Malayer city)" by strategic analysis, the factors affecting the development of rural entrepreneurship, in order of importance in determining, have been determined. اندح. The results of this study recommend moving in the form of a diversity strategy, ie creating a platform for participation.

Bahrampour (2014) in his article entitled "Employment-Entrepreneurship and Sustainable Rural Development" shows that rural development can be a factor in improving the living conditions of low-income people living in rural areas and their self-sufficiency in the process of macro development To know. Adopting an employment strategy for the villagers by supporting public policies based on directing investment, employment and services to rural areas leads to strengthening agriculture and changing agricultural production and natural resources and creating non-agricultural employment, increasing income and increasing Demand for local agriculture and non-agricultural products will increase. Establishment of rural companies, development of conversion industries and development and promotion of cooperatives and agricultural services is a desirable action to achieve the goal of rural development and entrepreneurship. 
Farahani et al. (2014) in a study entitled "Factors Affecting Entrepreneurship Growth in Rural Areas of Jaber Ansar County in Abdanan County" found that among the eight known factors, the most influential factor in terms of entrepreneurship and employment in The study area belongs to the infrastructural and social factor with a specific value of 5.63, which alone has explained $17.60 \%$ of the total variance. The next factors include economic factor, knowledge and awareness, self-confidence, individual creativity, innovation and creativity, physical infrastructure and access to economic facilities, which explained $72.5 \%$ of the variance.

Mollashahi and Tabrizi Dokhtfard (2014) in his article entitled "The importance of entrepreneurship and its role in the development of rural communities" while reviewing the concepts of entrepreneurship and entrepreneurship and its role and importance in the development of rural communities and then identifying obstacles and limitations Entrepreneurship expansion in rural areas have introduced three basic preconditions for entrepreneurship development in these areas, which are: development of entrepreneurship culture, entrepreneurship education and development of necessary infrastructure for entrepreneurship.

Manouchehri (2014) in his article entitled "Study of the role of rural handicrafts in entrepreneurship and job creation to attract tourism" The results show that one of the goals of entrepreneurship is sustainable rural development and in this regard to address rural industries, The conversion industry and the tourism industry and the creation of jobs such as the supply of handicrafts and basic household products, which reduces the migration of villagers to cities and represents the most attractive and ancient villages in Kermanshah province. The results indicate that there is a direct relationship between rural handicrafts and the attraction of tourism and entrepreneurship.

Rezaei (2014) in his article entitled "Study of the role and position of entrepreneurship in the development of rural cooperatives" has concluded that there is a close relationship between cooperatives and entrepreneurship and in fact entrepreneurship as one of the developments The key to the success of rural cooperatives. Cooperatives can increase their efficiency and effectiveness and operate more successfully by taking advantage of entrepreneurial elements such as creativity, innovation, identifying and taking advantage of opportunities and risk-taking. Accordingly, it is necessary to provide the necessary fields and support, including financial, legal, educational, consulting and information from relevant organizations and institutions to develop and strengthen entrepreneurship in cooperatives.

Valaei et al. (2015) in their article entitled "Analysis of Factors Affecting Sustainable Rural Development with Emphasis on Entrepreneurship (Case Study: Merhamatabad North - Miandoab County)" have concluded that the most important factor It has led to sustainable rural development, is an economic and personal factor. So that with the increase in the amount of facilities received such as self-employment loans, necessary and sufficient financial resources, job diversity has increased the motivation and individual morale to develop and expand entrepreneurship in the study area. Also, the infrastructure factor has the least impact among the eight factors in the development of entrepreneurship in the region.

Zargoosh and Mozaffari (2015) in their article entitled "The role of entrepreneurship in achieving sustainable rural employment, an effective step in implementing the Vision 1404 document" stated that rural entrepreneurship provides employment, income growth, wealth creation, quality improvement It is the life and help of local people to participate in the economy. Entrepreneurship and rural businesses are the potential capitals of the transformation of villages from the traditional to the active and economic sector and have a significant share in economic growth in society. They are accelerators to the country's economic growth.

Heidari-Mokrar and Sarani (2015) in their article entitled "Study and analysis of factors affecting the development of women entrepreneurship in rural areas" have concluded that entrepreneurship 
activities by women, a prominent role in the health of the nation's economy has. In a short time, women were able to make huge changes in the economic development of countries by entering the field of business. Because women can show their abilities through entrepreneurship, remove obstacles to the expression of their talents, and increase their courage more and more every day, women in developing countries are the first hope for family development. The growth and development of countries. The success of women entrepreneurs in these societies not only brings economic benefits but also social and cultural benefits.

Anbarloo and Heraini (2016) in their article entitled "The position of entrepreneurship in the sustainable development of rural settlements" have concluded that rural entrepreneurship is a new solution in development theories for empowerment and capacity building in rural areas to change The current way of life is a desirable and worthy human model, reducing the urban-rural gap, creating economic, social, environmental and institutional equality, and at the same time is an important tool to achieve sustainable development.

Pakzad (2016) in his article entitled "The role of handicrafts in women's entrepreneurship and economic development" shows that the entrepreneurship program of these women in the field of carpet weaving has led to the development of rural economy and up to eighty percent in the development of handicrafts Has played an important role. This trend is in line with the functional patterns that have elevated their position in the world economy in India and China.

Armaghan (2017) in a study entitled "Challenges and prospects of the role of entrepreneurship in rural development of Iran, villages of Baqershahr" found that rural entrepreneurship is a complex and delicate phenomenon that requires financial resources, environmental potential, desirable infrastructure facilities, expertise and education, Sustainability and environmental compatibility and all this requires innovation and creativity. The results also showed that challenges such as migration and environmental degradation as well as drought and inefficiency of the agricultural sector as well as pressures due to population growth and on the other hand the relative increase in education of rural residents, entrepreneurship has become a key variable in rural development in Iran. Is.

Safari Ali Akbari and Sadeghi (2017) in a study entitled "Analysis of the underlying factors for the creation and growth of rural entrepreneurship in Dehdez in Izeh" have concluded that the three indicators of creativity, risk-taking and independence of the people from the situation It has good and the three indicators of motivation to progress, produce new products and turn creative ideas into wealth are moderate. The socio-economic context as well as the characteristics of the people are ready to create various types of rural entrepreneurship and a good planning is needed for this purpose.

Alavizadeh (2017) in a study entitled "Entrepreneurship and its role in sustainable rural development (Case study: Ilam province)" has concluded that among the factors affecting entrepreneurship, the economic factor is the most effective factor in the study area. In the economic dimension, the bank lending index, with an average of 3.64, had the highest rank; The results also showed that rural entrepreneurship is one of the suitable contexts for creating employment in agricultural and non-agricultural sectors and one of the important factors in achieving sustainable development in rural areas.

Sig Ghoudhari (2018) in a study entitled "The role of entrepreneurship in rural development" stated that entrepreneurship is a tool to improve the quality of life of individuals, families and communities to maintain the economy. Entrepreneurship authorities for rural development accept entrepreneurship as the main force of economic growth and development. Accepting entrepreneurship as a force for development will not in itself lead to rural development and the development of rural enterprises. Rather, there is an urgent need for an entrepreneurial 
Evaluating the performance of modern rural management (Dehyari) in improving social contexts and attracting financial resources for the development of rural entrepreneurship in Khalilabad

environment in rural areas. The existence of such an environment depends on policies to promote rural entrepreneurship.

\section{Methodology}

The present research is applied in terms of purpose and descriptive-analytical in terms of method. Field and non-field methods were used to collect the required information, while in order to complete the questionnaires, the survey method was used and the questionnaires were distributed and collected within a month. In this study, the statistical population includes all villages with rural areas of Khalilabad city (23 villages with a population of 10,447 households). Considering that according to Cochran's formula, 21 villages should be studied as a sample, so since the difference between the statistical population and the sample population of the two villages is statistical, the statistical population will be examined as a sample. In this regard, according to the total number of households in the sample villages (10447 households) using the Cochran's formula, 370 questionnaires were distributed in the sample villages and completed by the heads of households.

\section{Results}

Table 1. Results of confirmatory factor analysis of questionnaire structures

\begin{tabular}{|c|c|c|c|c|c|}
\hline p-value & Statistics $\mathrm{t}$ & $\begin{array}{r}\text { Standard } \\
\text { deviation }\end{array}$ & $\begin{array}{r}\text { Standardized } \\
\text { coefficient }\end{array}$ & $\begin{array}{r}\text { Observed } \\
\text { variable } \\
\text { symbol } \\
\end{array}$ & Hidden variable \\
\hline & & & 729.0 & A8 & \multirow{14}{*}{$\begin{array}{l}\text { The role of rural } \\
\text { communities } \\
\text { improving the social } \\
\text { context } \\
\text { entrepreneurship } \\
\text { development }\end{array}$} \\
\hline 000.0 & 968.14 & 08.0 & 768.0 & A9 & \\
\hline 000.0 & 593.15 & 079.0 & 799.0 & A10 & \\
\hline 000.0 & 84.15 & 077.0 & 813.0 & A11 & \\
\hline 000.0 & 72.14 & 075.0 & 759.0 & A12 & \\
\hline 000.0 & 636.15 & 076.0 & 805.0 & A13 & \\
\hline 000.0 & 675.15 & 072.0 & 806.0 & A14 & \\
\hline 000.0 & 901.14 & 082.0 & 769.0 & A15 & \\
\hline 000.0 & 583.14 & 074.0 & 754.0 & A16 & \\
\hline 000.0 & 041.15 & 082.0 & 776.0 & A17 & \\
\hline 000.0 & 815.2 & 076.0 & 15.0 & A18 & \\
\hline 000.0 & 147.14 & 074.0 & .732 & A19 & \\
\hline 000.0 & 844.14 & 08.0 & 768.0 & A20 & \\
\hline 000.0 & 573.11 & 074.0 & 605.0 & A21 & \\
\hline 000.0 & & & 769.0 & A22 & \multirow{9}{*}{$\begin{array}{l}\text { The performance of } \\
\text { rural areas in attracting } \\
\text { financial resources for } \\
\text { entrepreneurship } \\
\text { development }\end{array}$} \\
\hline 000.0 & 097.17 & 07.0 & 825.0 & A23 & \\
\hline 000.0 & 179.17 & 066.0 & 824.0 & A24 & \\
\hline 000.0 & 93.13 & 061.0 & 692.0 & A25 & \\
\hline 000.0 & 836.13 & 066.0 & 693.0 & A26 & \\
\hline 000.0 & 152.16 & 067.0 & 792.0 & A27 & \\
\hline 000.0 & 528.14 & 071.0 & 723.0 & A28 & \\
\hline 000.0 & 586.15 & 067.0 & 767.0 & A29 & \\
\hline 000.0 & 038.17 & 065.0 & 821.0 & A30 & \\
\hline
\end{tabular}




\section{Questionnaire indicators}

Before determining the type of test used, especially in comparative tests, it is necessary to make sure that the variables are normal. One of the most important of these tests is the use of the Smirnov Kolmograph test. If the variables are normal, the use of parametric tests is recommended; otherwise, the use of equivalent non-parametric tests will be considered.

Table 2. Test the normality of research variables

\begin{tabular}{|c|c|c|c|c|c|c|c|}
\hline $\begin{array}{r}\text { Cronbach' } \\
\text { s alpha }\end{array}$ & $\begin{array}{r}\text { the } \\
\text { mos } \\
t\end{array}$ & $\begin{array}{r}\text { The } \\
\text { leas } \\
\mathrm{t}\end{array}$ & $\begin{array}{r}\text { Slendernes } \\
\text { s ratio }\end{array}$ & $\begin{array}{r}\text { Skewness } \\
\text { coefficien } \\
\mathrm{t}\end{array}$ & $\begin{array}{r}\text { Standard } \\
\text { deviatio } \\
n\end{array}$ & $\begin{array}{r}\text { Averag } \\
\mathrm{e}\end{array}$ & Variable \\
\hline 925.0 & 93.4 & 25.1 & -0.940 & 181.0 & 847.0 & 858.2 & $\begin{array}{l}\text { The role of rural } \\
\text { development in } \\
\text { improving the } \\
\text { social context of } \\
\text { entrepreneurshi } \\
\text { p development }\end{array}$ \\
\hline 896.0 & 78.4 & 00.1 & -0.673 & 127.0 & 906.0 & 744.2 & $\begin{array}{l}\text { The } \\
\text { performance of } \\
\text { villages in } \\
\text { attracting } \\
\text { financial } \\
\text { resources for } \\
\text { entrepreneurshi } \\
\text { p development }\end{array}$ \\
\hline
\end{tabular}

According to the above table, because Cronbach's alpha value is higher than $70 \%$, it shows that the items of the research tool have a high internal correlation and the research tool has good reliability. The collected data were processed using SPSS software and one-sample T method.

\section{Testing hypotheses}

Hypothesis 1: It seems that the performance of rural areas has improved the social context of entrepreneurship development.

This hypothesis can be examined as follows:

H_0: It seems that the performance of rural areas has not improved the social context of entrepreneurship development (average variable is not more than 3)

H_1: It seems that the performance of rural areas has improved the social context of entrepreneurship development (average variable is more than 3)

In order to compare the average opinions of respondents about the performance of rural areas to improve the social context of entrepreneurship development, the average of this variable was compared using the t-test with the number 3 (average), the results of which are listed in the table below:

Table 3. Results of comparison of the mean of the second hypothesis with the number 3 by t test 
Evaluating the performance of modern rural management (Dehyari) in improving social contexts and attracting financial resources for the development of rural entrepreneurship in Khalilabad

\begin{tabular}{|c|c|c|c|c|c|c|}
\hline $\begin{array}{l}\text { The result } \\
\text { of the } \\
\text { hypothesis }\end{array}$ & $\begin{array}{c}\mathrm{p}- \\
\text { value }\end{array}$ & $\begin{array}{l}\text { Degrees } \begin{array}{r}\text { of } \\
\text { freedom }\end{array}\end{array}$ & $\begin{array}{r}\text { Statistic } \\
\mathrm{s} \mathrm{t}\end{array}$ & $\begin{array}{r}\text { Standar } \\
\mathrm{d} \\
\text { deviatio } \\
\mathrm{n}\end{array}$ & $\begin{array}{r}\text { Averag } \\
\mathrm{e}\end{array}$ & Survey \\
\hline $\begin{array}{r}\text { disapprova } \\
1\end{array}$ & 001.0 & 368 & -3.229 & 847.0 & 858.2 & $\begin{array}{l}\text { The role of rural } \\
\text { development in } \\
\text { improving the } \\
\text { social context } \\
\text { of } \\
\text { entrepreneurshi } \\
\text { development }\end{array}$ \\
\hline
\end{tabular}

According to the results of the above table According to the results of the above table, since the average (2.858) is less than 3 , so the null hypothesis that the performance of rural areas has not improved the social context of entrepreneurship development is accepted and the second hypothesis of the research is not confirmed To be.

Hypothesis 2: It seems that the performance of rural areas has attracted financial resources for the development of entrepreneurship.

This hypothesis can be examined as follows:

H_0: It seems that the performance of rural areas has not attracted financial resources for entrepreneurship development (average variable is not more than 3 )

H_1: It seems that the performance of rural areas has attracted financial resources for the development of entrepreneurship (average variable is more than 3 )

In order to compare the average opinions of respondents on the performance of rural areas in attracting financial resources for entrepreneurship development, the average of this variable was compared using t-test with the number 3 (average), the results of which are also listed in the table below:

Table 4. Results of comparison of the mean of the third hypothesis with the number 3 by t test

\begin{tabular}{|c|c|c|c|c|c|c|}
\hline $\begin{array}{l}\text { The result } \\
\text { of the } \\
\text { hypothesis }\end{array}$ & $\begin{array}{r}p- \\
\text { value }\end{array}$ & $\begin{array}{l}\text { Degrees } \begin{array}{r}\text { of } \\
\text { freedom }\end{array}\end{array}$ & $\begin{array}{r}\text { Statistic } \\
\mathrm{s} \mathrm{t}\end{array}$ & $\begin{array}{r}\text { Standar } \\
\mathrm{d} \\
\text { deviatio } \\
\mathrm{n}\end{array}$ & $\begin{array}{r}\text { Averag } \\
\mathrm{e}\end{array}$ & Survey \\
\hline $\begin{array}{r}\text { disapprova } \\
1\end{array}$ & 001.0 & 368 & -5.424 & 906.0 & 744.2 & $\begin{array}{l}\text { The } \\
\text { performance of } \\
\text { villages in } \\
\text { attracting } \\
\text { financial } \\
\text { resources for } \\
\text { entrepreneurshi } \\
\text { p development }\end{array}$ \\
\hline
\end{tabular}

According to the results of the above table, since the average (2.744) is less than 3 , so the null hypothesis that the performance of rural areas has not attracted financial resources for entrepreneurship development has been accepted and the third hypothesis of the research. Not approved.

\section{Discussion and conclusion}


The emergence of rural society from problems such as unemployment, underdevelopment and economic growth depends on the development and support of rural entrepreneurs. Entrepreneurship development can play a key role in solving the above problems and as an appropriate strategy for rural development by increasing public participation and activating social capital and using the financial and human resources available in the regions, remove the obstacles in this area. $\mathrm{N}$.

Rural entrepreneurship; Reducing unemployment, increasing the productivity of people and resources, increasing income, improving the economic situation and empowerment of rural communities, and thus it is called as an appropriate and effective strategy to accelerate the flow of rural development.

In the villages, naturally, there are unknown capacities to launch entrepreneurial activities, which the villagers can use to better plan, create jobs and entrepreneurship, and achieve the desired result. Although it should not be said that entrepreneurship is the only way to create jobs and increase the incomes of rural people, but it can certainly be said that it is the best type.

According to the results obtained in rural areas, satisfaction with the performance of rural areas in improving social conditions and attracting financial resources for the development of rural entrepreneurship is less than average. The results of testing the hypotheses showed that the villagers of Khalilabad city were not successful in developing rural entrepreneurs and had poor performance.

Table 5. Issues and problems and solutions

\begin{tabular}{|c|l|}
\hline solutions & issues and problems \\
\hline $\begin{array}{l}\text { Holding training courses before taking } \\
\text { office }\end{array}$ & $\begin{array}{l}\text { Insufficient knowledge of entrepreneurs } \\
\text { about entrepreneurship and the process of } \\
\text { creating it }\end{array}$ \\
\hline $\begin{array}{l}\text { Government assistance according to } \\
\text { the special circumstances of the } \\
\text { villagers }\end{array}$ & $\begin{array}{l}\text { Weak financial strength of villagers to } \\
\text { provide the necessary capital for } \\
\text { entrepreneurship }\end{array}$ \\
- $\begin{array}{l}\text { Forming an entrepreneurial } \\
\text { cooperative company }\end{array}$ & \\
\hline $\begin{array}{l}\text { Introducing the potentials of villages } \\
\text { to non-native investors }\end{array}$ & $\begin{array}{l}\text { Creating grounds for attracting the } \\
\text { participation of villagers }\end{array}$ \\
$\begin{array}{l}\text { Scoring villagers when evaluating } \\
\text { their performance }\end{array}$ & $\begin{array}{l}\text { Inadequate communication between Dehyar } \\
\text { and the villagers (separation of Dehyar from } \\
\text { the villagers) }\end{array}$ \\
\hline
\end{tabular}

\section{References}

Hashemi Seyed Saeed, Seyed Hassan Motiee Langroudi, Mojtaba Ghadiri Masoom, Mohammad Reza Rezvani, Seyed Mohammad Moghimit. (2011). Explaining the Role of Islamic Villages and Councils in Rural Entrepreneurship Development (Case Study: Bahabad, Yazd Province), Journal of Rural Research, Second Year 'Issue 1, Spring 2011.

Heaton, J. (2005). Developing entrepreneurs an examination .of systematic approochs to entrepreneurial development for rural research report.

Rezvani Mohammad Reza. (2004). Introduction to Rural Development Planning in Iran, Qoms Publishing. Rural journal, 7, 89-101. 
Rezvani, Mohammadreza Hamkaran. (2008). Study and analysis of rural entrepreneurship in the process of rural development in a case study of rural South Baraan. Isfahan city, Quarterly Journal of Entrepreneurship Development.

Rokanuddin Eftekhari, Abdolreza and Sajasi Gheidari, Hamdaleh. (2010). Rural Development with Emphasis on Entrepreneurship, Organization for the Study and Compilation of University Humanities Books - Position.

Safety, Siavash and Hashemi Seyed Saeed. (2009). The Role of Entrepreneurship in Sustainable Tourism Development, Journal of Labor and Society, No. 106.

Yadalahi Jahangir. (2015). Entrepreneurship Development Planning Model, Proceedings of the National Conference on Entrepreneurship, Islamic Azad University of Roodehen.

YoncaGurol and NurayAtsan. (2006). Entrepreneurial characteristics amongst university students Some insights for entrepreneurship education and training in Turkey, Education + Training, Vol. 48 No. 1. 